\title{
Primary School Students' Attitudes towards Reading
}

\author{
Hatice Vatansever Bayraktar ${ }^{1} \&$ Buket Acikses Firat ${ }^{2}$ \\ ${ }^{1}$ Phd., Assoc. Prof, İstanbul Sabahattin Zaim University, Education Faculty, Teacher Training at Primary School \\ Level, Turkey \\ ${ }^{2}$ Primary School Teacher, Ministry of Education, Turkey \\ Correspondence: Hatice Vatansever Bayraktar, Phd., Assoc. Prof, https://orcid.org/0000-0002-0458-3405, \\ İstanbul Sabahattin Zaim University, Education Faculty, Teacher Training at Primary School Level, Turkey. \\ E-mail: hatice.bayraktar@izu.edu.tr
}

Received: September 26, 2020

Accepted: November 3, $2020 \quad$ Online Published: November 12, 2020

doi:10.5539/hes.v10n4p77

URL: https://doi.org/10.5539/hes.v10n4p77

\begin{abstract}
The purpose of this study is to examine the level of primary school students' attitudes towards reading and whether they differ according to various variables. Descriptive scanning model was used in the research. The universe of the research consists of primary school students studying in the 2nd, 3rd and 4th grades in Istanbul. The sample of the study consists of 534 primary school students who study in 2, 3 and 4 classes in primary schools in Avcilar and Beylikdüzü districts of Istanbul. In the research, "Personal Information Form" and "Reading Attitude Scale" were used as data collection tools. SPSS was used in the analysis of the data. As a result of data analysis, it was observed that primary school students' attitudes towards reading were high. The attitudes of primary school students towards reading show a statistically significant difference in the total scores, in the reading for fun and in the academic reading sub-dimensions according to variables of gender, book-magazine reading status and state of enjoying the gift of books. The attitudes of female students, those who read books and magazines, and those who like to give books to them are higher. The attitudes of primary school students towards reading show a statistically significant difference according to the variable of buying book magazines to read in the sub-dimension of reading for entertainment and in the total scores. This difference is in favor of those who buy book and magazines to read. The attitudes of primary school students towards reading show a statistically significant difference in sub-dimension of reading for entertainment purposes according to the number of siblings. The attitudes of primary school students towards reading show a statistically significant difference in the total scores, in the reading for fun and in the academic reading sub-dimensions according to the variables of the class she studied and the number of books read per week. Primary school students' attitudes towards reading do not show a statistically significant difference according to variables.of mother and father educational status and favorite book type.
\end{abstract}

Keywords: reading, attitude, reading attitude, primary school

\section{Introduction}

The education of a child first begins in the family. The acquisition of basic skills, the habit of obeying certain rules, and, therefore, the first step into social life start with the family and take shape at school when the child reaches sufficient maturity. With the school, the child starts to acquire skills and behaviors related to teaching and education. The most important one of these skills and behaviors is that the child learns to read and write. The first reading and writing is a basic learning skill. However, it does not end with learning to read and write. When the educational life is considered, literacy, which forms the basis of other learning, is a basic communication tool for students. Children who have learned how to read and write in a robust way become successful not only in understanding what they read and writing, and in Turkish, but also all other subjects such as social studies, science and technology, and mathematics throughout their educational lives. Children who develop good literacy skills, especially in the first grades, better understand and benefit from the materials presented to them in advanced grades and perform better studies. The more robust the literacy skill in the first years of education is, the higher the success in educational life is. In other words, literacy is a factor that determines an individual's academic achievement and is an important factor in personal development (Vatansever, 2008). In this context, the literacy skill acquired in primary school and the positive attitude towards reading positively affect students' willingness to read, their enjoyment of reading, their reading comprehension skills, and their academic 
achievement.

Reading is the process of interpreting and internalizing the text, which is a linguistically coded production with its physical, mental, and sociological aspects, by interpreting it with a critical approach (Yalınkılıç, 2007). Şahin (2009), who stated that reading is the job of seeing, perceiving, comprehending and vocalizing written symbols, indicated that the most important of these elements is the formation of understanding. Coşkun (2002) defined reading as "A complex mental process consisting of different components such as seeing, attention, perception, remembering, vocalization, explanation, synthesis, analysis, and interpretation."

According to the constructivist approach, reading is an active process in which the individual creates new meanings by combining his/her prior knowledge with the information in the text. In the reading process, the individual investigates, finds, interprets, and re-interprets the meaning of the writings (Güneş, 2009). According to Özdemir (2005), reading, which is a mental and intellectual act with a simple definition, is perceiving, comprehending, and interpreting printed or written words through our sensory organs and is a communicative activity that is realized through printed and written symbols. According to the definition of Yildiz et al. (2006), the reading activity is a complex process with physiological, mental, and spiritual aspects, which includes the analysis and evaluation of the emotions and thoughts in the text through their comprehending. Kavcar et al. (1995) defined reading as "the process of seeing, perceiving, and comprehending a text, words, sentences, punctuation marks, and other elements," and reading takes a very important place in human life. A person who has acquired the act of reading becomes successful both in his/her academic life and in his/her professional career, and it is said that he/she can reach the consciousness of how to use his/her free time efficiently. Reading has a social and economic function in terms of creating ways of communication at different levels between individuals and groups and increasing these relationships (Günay, 2003). Reading, which constitutes the basis of learning, is a complex process consisting of various functions of the eyes, voice, and brain such as seeing, perception, vocalization, understanding, and mental configuration and is affected by many factors (Güneş, 2009). Reading is not an activity that starts and ends only in a certain part of human life. It is an act that lasts for the whole life and has an important place and function in forming the thoughts, behaviors, and personalities of individuals. Reading is one of the most important phenomena related to the individual's understanding of the reason for his/her existence, forming his/her thoughts, determining his/her place in society, and revealing his/her individuality. To become mature, respectful, sensitive, and contemporary persons with creative, productive and critical thinking skills, we need to acquire the act of reading (İşeri, 1998).

Reading broadens and deepens a person's horizons by developing the vocabulary and creativity of the individual and enriching his/her imagination (Akyol, 2011). It educates the individual's feelings and thoughts and improves knowledge, manners, and tolerance (Calp, 2010). Since the acquisition of knowledge is the most important gain obtained by reading, reading is the most basic need for a person who conducts research and questions (Aktaş and Gündüz, 2004).

If we need to deduce from the definitions, for reading to occur, reading is a dynamic process of making meaning, and it enables active and necessary communication between the writer and the reader. The main purpose of teaching reading is to ensure that the child uses the writing and drawing language effectively in establishing communication (Akyol, 2011). The taste we get when we read a book in childhood and the taste we get from it when we read it in adulthood differ (Özdemir, 2005) because our way and level of being affected by the factors that affect reading and that we have listed change over time.

Reading education in Turkey is generally carried out by vocalizing the text of a textbook in sections in line with the relevant instructions. However, teaching reading is a comprehensive process that includes what a student should pay attention to while reading a text, how to make inferences from the text, and how to behave against different text types (Topuzkanamış and Maltepe, 2010).

The period when the human mind works and develops most rapidly is the primary school period. This period is the time when the child questions everything that happens around him/her. Reading helps children to think, to ask the right questions about what they want to learn and to give correct answers to them (Sünbül et al., 2010). The improvement and maintenance of the reading skill depend on the foundations laid in the primary education period. The more solid and healthier foundation is laid during this period, the more successful the development will be in the future periods. At the end of the compulsory primary education that is given until the end of the age of 15 , students are expected to reach a level at which they can read 400 words per minute vocally and 600-700 words silently (Özbay, 2006).

The National Educational Evaluation Survey conducted in the United States of America in 2000 showed that 37\% of $4^{\text {th }}$-grade students could read only at the beginning level. In English-speaking countries, students learn to read 
up to the $4^{\text {th }}$ grade, and then they read to learn after the $4^{\text {th }}$ grade. The reason why this process starts so late is that the pronunciation and spelling of English words are different from each other. Since words are read as they are written to a large extent in Turkish, students learn how to read until the end of the first grade (Savaş, 2006). Students who have learned to read understand the meanings of words, sentences, and paragraphs by concentrating their attention. They choose the information they are interested in and find necessary from words, sentences, and paragraphs. They perform high-level mental operations such as ordering, classifying, questioning, relating, criticizing, analyzing, problem-solving, evaluating, and synthesizing in line with the selected information (Güneş and Akyol). With reading, students acquire one of the most effective tools to develop language and personality systematically (Özbay, 2009). The attitude that students who learn to read develop towards reading is important both during their academic life and for their future life periods. Students who develop a positive attitude towards reading are more likely to enjoy what they read, become a good reader, understand what they read better, and have higher academic achievement.

The reading skill acquired in primary school affects students' further learning positively or negatively. Students develop an attitude towards reading in this process. To achieve the individual and social benefits expected from reading education, first of all, individuals should love to read and not avoid reading. At this point, the need to develop a positive attitude towards reading emerges (Akkaya and Özdemir, 2013: 77).

According to Smith, the attitude is a tendency that is attributed to an individual and regularly forms his/her thoughts, feelings, and behaviors related to the psychological object (Kağıtçıbaşı, 1992; as cited in Vatansever-Bayraktar and İşleyen, 2018). The attitude is defined as "a preliminary tendency to a mental, emotional, and behavioral reaction that an individual organizes against himself/herself or any object, social issue, or event around him/her based on experience, knowledge, emotion, and motivation" (İnceoğlu, 2010). The attitude is a psychological construct that is regarded as an important and critical predictor of an individual's behaviors with its cognitive, affective, and behavioral dimensions (Anderson 1988; Kan and Akbaş, 2005; as cited in Vatansever-Bayraktar, Kadıŏlu-Ateş and Afat, 2019).

The most important feature that distinguishes a human from other living beings is his mind. In this way, the individual perceives his/her environment, the culture, society and the world he/she is in. One of the important factors that contribute to a person's taking action while performing these actions is the attitude. The number of investigations on attitudes among the studies carried out to increase efficiency in education is increasing every day. The researchers have made different definitions of the concept of attitude. Attitudes form a need for information that enables individuals to develop some basic criteria in understanding and interpreting the world (İsen and Batmaz, 2002). The attitude is a permanent trait tendency that affects the individual's emotions, thoughts, and behaviors by affecting his/her cognitive, affective, and psychomotor behaviors as a result of his/her interaction with his/her environment (Başaran and Ateş, 2009). As seen in other psychological variables, attitudes are hidden and theoretical variables that cannot be observed directly. The existence and dimensions of attitudes can only be understood by observing the behaviors they affect. Therefore, it is possible to mention a parallel relationship between attitudes and behaviors (İnceoğlu, 2004). To measure attitudes, it is necessary to investigate and know the existence of an attitude and to observe the behavior of an individual. The reason for this is that an attitude can be measured indirectly, in other words, by examining the individual's responses to the attitude items since the attitude is a mental preparation behind the behavior (Silah, 2000). In this respect, the attitude takes an important place in the learning-teaching process because the student's positive attitudes towards elements such as the subject, school, teacher, etc. will increase his/her achievement in the teaching process (Açıkgöz, 1992). This power has enough effect even to activate the individual. With this movement, the individual performs the act of reading that continues from the past to the present day in order to meet the learning need. It is thought that the attitude of the person affects the reading activity.

The reading attitude is defined as children's views on enjoying and appreciating a book. It is within the vision of the Turkish course that a child enjoys reading and learning. The studies draw attention to the fact that the development of reading and reading comprehension skills, which are the most important elements of the learning process, is directly related to students' attitudes towards reading. It is known that students who have a positive attitude towards reading learn more effectively and efficiently. Furthermore, students' attitudes towards reading also affect their academic achievement and cognitive learning levels in general (Şahin-Taşkın and Esen-Aygün, 2017).

General reading attitude is defined as reading material characteristic of most types of reading; readings which enhance personal growth and self-fulfillment. Academic attitude toward reading material is defined as reading for the acquisition of knowledge about content areas, correct language usage, and understanding grammar. Vocational attitude toward reading material is defined as reading material which has as its goal the preparation of 
readers for the world of work; readings directly related to applying for and maintaining a job (Moore and Lemons, 1982).

Recent research on literacy has highlighted the impact of affective factors on learning to read. Among these factors, attitudes toward reading have been clearly shown to influence the development of reading skills and academic success (Nootens et al, 2019).

There are many factors that affect attitudes towards reading. As stated by Temple et al. (2005), the US National Research Council listed some attitudes and behaviors that may affect children's attitudes towards reading as follows:

1. Value Given to Literacy: Children to whom books are read and who are encouraged to read books realize the value of reading.

2. Emphasis on Success: Parents' expressing their expectations about children's achievements, providing them with instructions for this, and meeting their reading interests can be effective in making children good readers.

3. Accessibility and Usability of Reading Material: Having children's books and other reading and writing materials at home increases literacy experiences.

4. Reading to Children: Parents can increase their children's positive attitudes towards reading by reading books to them before going to bed and at other times in the pre-school period (as cited in Başaran and Ateş, 2009, pp. 77-78).

If the factors for reading mentioned above are acquired, the possibility of the child developing a positive attitude towards reading is also increased.

It is necessary to take into account the characteristics of developmental periods to make a child acquire a positive attitude towards reading and to ensure that the reading habit is established (Akkaya and Özdemir, 2013). The literature demonstrates that primary school children have low attitudes towards reading and that the child's family, environment, home environment, and many other factors affect their reading attitudes (Başaran and Ateş, 2009). According to the research, attitude development differs according to age: It was found that attitudes acquired between the ages of 1-7 years can usually maintain their effects throughout life. It is not possible to completely erase the attitudes of students that are settled at this age but do not comply with the educational objectives. The undesired attitudes can either be replaced by others, or their damage is reduced by minimizing their renewal, or they can be directed towards areas where they will be necessary (Başaran, 1988). It has been revealed that while some attitudes of primary school students aged between 6-12 years change, some remain the same and that the attitudes towards the status of the family are strong (Ülgen, 1997). Parents and friends are the most influential people in the attitudes formed by children (Kağıtçıbaşı, 1993).

The changes that parents make in home conditions for their children can also affect their children's attitudes towards reading. For example, having a study room and a bookcase at home, and activities such as the regular buying of books, magazines, or newspapers to home, arranging environmental conditions for children after they start reading, etc. will increase children's positive attitudes towards reading (Başaran and Ateş, 2009: 77).

The studies demonstrate a positive relationship between children's reading skills and their attitudes towards reading, in other words, those who can read better love to read more (Groff, 1962; as cited in Dökmen, 1994). In reading comprehension studies, students' positive attitudes towards reading will enable more effective and efficient learning. There is also a linear relationship between students' reading comprehension achievements and their attitudes towards reading. In the study conducted, Smith (1991) found a linear relationship between individuals' attitudes towards reading and their reading behaviors and activities. As a result of his study, Altunay (2000) found that students with a positive attitude towards reading benefited more from pre-organizers and the achievement of students with a negative attitude towards reading decreased gradually. Thus, improving the reading comprehension process and making it effective depend only on the formation of positive attitudes towards reading and knowing how to become more successful in this process. Therefore, attention should be paid to reading comprehension studies and developing positive attitudes towards reading (Güngör and Açıgöz, 2006).

Among the studies conducted from the past to the present, there are studies showing that the attitude takes an important place in people's reading habits. Reading is a skill that can be developed and improved (Akçamete and Güneş, 1992). Reading is important learning that should be acquired in an individual's life. Reading is an important skill that must be acquired both in school life and in daily life. The reading habit is an important key for the child in his/her mental, personality, language and social development, in the development of thinking power, and in becoming more efficient and successful in education (Yılmaz, 2000). Raising individuals who can 
read correctly and fluently, can make sense of what they read and transmit it verbally and in writing is very important in terms of a person's academic and social life (Çeliktürk and Yamaç, 2015). Despite an increasing emphasis on reading comprehension in recent studies, it is known that students' attitudes towards reading take an important place in improving their reading skills. There is a meaningful relationship between the reading skill acquired by an individual and other skills that have been acquired or will be acquired. This relationship may occur in the form of skills complementing or supporting each other, or it can be in the form of achieving the same goal (Aric1, 2012). The critical role of the reading skill from the first years of school life imposes significant responsibilities on teachers and parents for their children to develop a positive reading attitude and thus become good readers (Kocaarslan, 2016).

The attitude of an individual towards reading will affect learning positively or negatively. The individual progresses in waves from the family environment where he has started life to developing these factors and reflects them on the whole area. Attitudes tend to be affected by family members or other people with whom they have relationships, especially in childhood (Özbay, 2009: 68). An individual who comes to school for the reading activity after his/her family life develops an attitude in the school he/she has started with his/her personal structure. Moreover, factors such as the individual's gender, age, the number of siblings, the financial status of the family, and the educational status of the family are thought to affect the individual's attitude towards reading.

There are many studies in the international literature that evaluate the attitudes of primary school students towards reading. Furthermore, it has been emphasized that there is a relationship between students' attitudes towards reading and their reading achievement, and students with high reading attitudes also have high reading comprehension skills (Şahin-Taşkın and Esen-Aygün, 2017). It is observed that there are studies that examine reading attitudes and reading comprehension skills in Turkey (Açıkgöz and Güngör, 2006; Sallabaş, 2008). The findings obtained from these studies, which are generally performed with secondary school students, emphasize that there is a relationship between students' attitudes towards reading and their reading comprehension skills (Açıkgöz and Güngör, 2006; Balcı, Uyar and Büyükikiz, 2012; Sallabaş, 2008). There are few studies dealing with the reading attitudes of primary school students. In these few studies, the relationship between reading attitudes and achievement was revealed, and it was emphasized that factors such as parental attitude, the income level of the family, and education level affect this relationship (Akyol and Temur, 2008; Kovacioğlu, 2006). The literature draws attention to the fact that the reading comprehension skill, which plays an essential role in students' academic achievement, is related to their attitudes towards reading. Accordingly, it is important to develop the reading attitude in the primary school period when students learn and improve literacy. Findings to be obtained from the research to be conducted to this end will provide us with information about how we can help students develop a positive attitude towards reading. Thus, it is thought that it will contribute to the increase in students' reading achievement and, consequently, their achievement in other courses.

\subsection{Aim of the Study}

The aim of this study is to examine the level of primary school students' attitudes towards reading and whether they differ according to various variables. Within the framework of this general aim, answers to the following questions will be sought:

1. What is the level of primary school students' attitudes towards reading?

2. Do primary school students' attitudes towards reading differ significantly by gender?

3. Do primary school students' attitudes towards reading differ significantly according to their status of reading books and magazines?

4. Do primary school students' attitudes towards reading differ significantly according to their status of liking being gifted with a book?

5. Do primary school students' attitudes towards reading differ significantly according to the number of siblings?

6. Do primary school students' attitudes towards reading differ significantly according to their grade level?

7. Do primary school students' attitudes towards reading differ significantly according to the number of books they read per week?

8. Do primary school students' attitudes towards reading differ significantly according to their parents' educational status?

9. Do primary school students' attitudes towards reading differ significantly according to their favorite type of book? 


\section{Method}

\subsection{Research Method}

The descriptive survey model was used in the study to describe the attitudes of primary school students towards reading. In survey models, which are a research approach that aims to describe a past or present situation as it is, the individual or object, which is the research subject, is tried to be defined in its own conditions and as it is (Karasar, 2016).

\subsection{Population and Sample}

The universe of the research consists of primary school students studying in the 2nd, 3rd and 4th grades in Istanbul. The sample of the study consists of a total of 534 primary school students studying in the $2^{\text {nd }}, 3^{\text {rd }}$, and $4^{\text {th }}$ grades of primary school in Avcılar and Beylikdüzü districts in Istanbul province in the second semester of the 2017-2018 academic year.

The distribution of the sample group according to their demographic characteristics is presented in the tables below.

Table 1. Distribution of Students by the Gender Variable

\begin{tabular}{lllll}
\hline Gender & Frequency & Percent & Valid percent & Cumulative percent \\
\hline Female & 254 & 47,6 & 47,6 & 47,6 \\
Male & 280 & 52,4 & 52,4 & 100,0 \\
Total & 534 & 100,0 & 100,0 & \\
\hline
\end{tabular}

According to Table 1, when the distribution of the primary school students participating in the study according to the gender variable was examined, it was determined that 254 of 534 students were female $(47.6 \%)$, and 280 were male $(52.4 \%)$.

Table 2. Distribution of Students by the Grade Level Variable

\begin{tabular}{lllll}
\hline Grade Level & Frequency & Percent & Valid percent & Cumulative percent \\
\hline 2nd grade & 60 & 11,2 & 11,2 & 11,2 \\
3rd grade & 264 & 49,4 & 49,4 & 60,7 \\
4th grade & 210 & 39,3 & 39,3 & 100,0 \\
Total & 534 & 100,0 & 100,0 & \\
\hline
\end{tabular}

According to Table 2, when the distribution of the primary school students participating in the study according to their grade level variable is examined, it is observed that 60 out of 534 students (11.2\%) are $2^{\text {nd }}$ grade, 264 $(49.4 \%)$ are $3^{\text {rd }}$ grade, and $210(39.3 \%)$ of them are $4^{\text {th }}$ grade students.

Table 3. Distribution of Students by the Variable of the Number of Books They Read per Week

\begin{tabular}{lllll}
\hline Number of Books They Read per Week & Frequency & Percent & Valid percent & Cumulative percent \\
\hline do not read at all & 23 & 4,3 & 4,3 & 4,3 \\
read one book per week & 158 & 29,6 & 29,6 & 33,9 \\
read two books per week & 192 & 36,0 & 36,0 & 69,9 \\
read three books per week & 65 & 12,2 & 12,2 & 82,0 \\
read four and more books per week. & 96 & 18,0 & 18,0 & 100,0 \\
Total & 534 & 100,0 & 100,0 & \\
\hline
\end{tabular}

According to Table 3, when the distribution of the primary school students participating in the study according to the variable of the number of books they read per week is examined, it is observed that 23 of 534 students (4.3\%) do not read at all, $158(29.6 \%)$ read one book per week, 192 of them (36\%) read two books per week, 65 of them $(12.2 \%)$ read three books per week, and 96 of them (18\%) read four and more books per week. 
Table 4. Distribution of Students According to The Variable of Their Status of Reading Books and Magazines

\begin{tabular}{lllll}
\hline $\begin{array}{l}\text { Their Status of Reading } \\
\text { Books and Magazines }\end{array}$ & Frequency & Percent & Valid percent & Cumulative percent \\
\hline Yes & 350 & 65,5 & 65,5 & 65,5 \\
No & 184 & 34,5 & 34,5 & 100,0 \\
Total & 534 & 100,0 & 100,0 & \\
\hline
\end{tabular}

According to Table 4, when the distribution of the primary school students participating in the study according to the variable of their status of reading books and magazines was examined, it was determined that $350(65.5 \%)$ of 534 students read books and magazines, and 184 (34.5\%) did not read books and magazines.

Table 5. Distribution of Students by the Favorite Book Type Variable

\begin{tabular}{lllll}
\hline Favorite Book Type & Frequency & Percent & Valid percent & Cumulative percent \\
\hline story & 210 & 39,3 & 39,3 & 39,3 \\
fairy tale & 181 & 33,9 & 33,9 & 73,2 \\
tales & 82 & 15,4 & 15,4 & 88,6 \\
humor & 40 & 7,5 & 7,5 & 96,1 \\
other type of books & 21 & 3,9 & 3,9 & 100,0 \\
Total & 534 & 100,0 & 100,0 & \\
\hline
\end{tabular}

According to Table 5, when the distribution of the primary school students participating in the study according to their favorite book type variable is examined, it is observed that $210(39.3 \%)$ out of 534 students like stories, 181 of them (33.9\%) like fairy tales, $82(15.4 \%)$ of them like tales, $40(7.5 \%)$ of them like humor, and $21(3.9 \%)$ of them like the other type of books.

Table 6. Distribution of Students by the Variable of the Status of Buying Books and Magazines to Read

\begin{tabular}{lllll}
\hline $\begin{array}{l}\text { Status of Buying Books and } \\
\text { Magazines to Read }\end{array}$ & Frequency & Percent & Valid percent & Cumulative percent \\
\hline Yes & & & & \\
No & 404 & 75,7 & 75,7 & 75,7 \\
Total & 130 & 24,3 & 24,3 & 100,0 \\
\hline
\end{tabular}

According to Table 6, when the distribution of the primary school students participating in the study by the variable of the status of buying books and magazines to read was examined, it was revealed that 404 (75.7\%) out of 534 students bought books and magazines to read, while 130 (24.3\%) did not buy books and magazines.

Table 7. Distribution of Students by the Variable of the Status of Liking Being Gifted with a Book

\begin{tabular}{lllll}
\hline Status of Liking Being Gifted with a Book & Frequency & Percent & Valid percent & Cumulative percent \\
\hline Yes & 493 & 92,3 & 92,3 & 92,3 \\
No & 41 & 7,7 & 7,7 & 100,0 \\
Total & 534 & 100,0 & 100,0 & \\
\hline
\end{tabular}

According to Table 7, when the distribution of the primary school students participating in the study according to the variable of the status of liking being gifted with a book was examined, it was found that $493(92.3 \%)$ out of 534 students liked being gifted with a book, and $41(7.7 \%)$ did not like being gifted with a book.

Table 8. Distribution of Students by the Variable of the Number of Siblings

\begin{tabular}{lllll}
\hline Number of Siblings & Frequency & Percent & Valid percent & Cumulative percent \\
\hline only child & 43 & 8,1 & 8,1 & 8,1 \\
one sibling & 102 & 19,1 & 19,1 & 27,2 \\
two siblings & 179 & 33,5 & 33,5 & 60,7 \\
three siblings & 116 & 21,7 & 21,7 & 82,4 \\
four siblings & 70 & 13,1 & 13,1 & 95,5 \\
five and more siblings & 24 & 4,5 & 4,5 & 100,0 \\
Total & 534 & 100,0 & 100,0 & \\
\hline
\end{tabular}


According to Table 8, when the distribution of the primary school students participating in the study by the variable of the number of siblings is examined, it is observed that $43(8.1 \%)$ out of 534 students are the only child, $102(19.1 \%)$ have one sibling, 179 (33.5\%) have two siblings, $116(21.7 \%)$ have three siblings, $70(13.1 \%)$ have four siblings, and 24 (4.5\%) have five and more siblings.

Table 9. Distribution of Students by the Variable of the Mother's Educational Status

\begin{tabular}{lllll}
\hline Mother's Educational Status & Frequency & Percent & Valid percent & Cumulative percent \\
\hline illiterate & 71 & 13,3 & 13,3 & 13,3 \\
primary school graduates & 150 & 28,1 & 28,1 & 41,4 \\
secondary school graduates & 150 & 28,1 & 28,1 & 69,5 \\
high school graduates & 115 & 21,5 & 21,5 & 91,0 \\
university graduates & 32 & 6,0 & 6,0 & 97,0 \\
have a master's degree & 16 & 3,0 & 3,0 & 100,0 \\
Total & 534 & 100,0 & 100,0 & \\
\hline
\end{tabular}

According to Table 9, when the distribution of the primary school students participating in the study by the variable of the mother's educational status is examined, it is observed that the mothers of $71(13.3 \%)$ of the 534 students are illiterate, mothers of 150 students $(28.1 \%)$ are primary school graduates, mothers of 150 students (28.1\%) are secondary school graduates, mothers of 115 students $(21.5 \%)$ are high school graduates, mothers of 32 students $(6.0 \%)$ are university graduates, and mothers of 16 students (3.0\%) have a master's degree.

Table 10. Distribution of Students by the Variable of the Father's Educational Status

\begin{tabular}{cllll}
\hline Father's Educational Status & Frequency & Percent & Valid percent & Cumulative percent \\
\hline illiterate & 34 & 6,4 & 6,4 & 6,4 \\
primary school graduates & 117 & 21,9 & 21,9 & 28,3 \\
secondary school graduates & 151 & 28,3 & 28,3 & 56,6 \\
high school graduates & 141 & 26,4 & 26,4 & 83,0 \\
university graduates & 65 & 12,2 & 12,2 & 95,1 \\
have a master's degree & 26 & 4,9 & 4,9 & 100,0 \\
Total & 534 & 100,0 & 100,0 & \\
\hline
\end{tabular}

According to Table 10, when the distribution of the primary school students participating in the study by the variable of the father's educational status is examined, it is observed that the fathers of $34(6.4 \% \%)$ of the 534 students are illiterate, fathers of 117 students $(21.9 \%)$ are primary school graduates, fathers of 151 students (28.3\%) are secondary school graduates, fathers of 141 students $(26.4 \%)$ are high school graduates, fathers of 65 students $(12.2 \% \%)$ are university graduates, and fathers of 26 students $(4.9 \% \%)$ have a master's degree.

\subsection{Data Collection}

The "Personal Information Form" and the "Attitude Towards Reading Scale" developed by Kocaarslan (2016) were used as data collection tools in the study. The scale has two sub-scales: "leisure reading" (Items 1-10) and "academic reading" (Items 11-20). The scale consists of a total of 20 items. This scale, which is very useful for application in the classroom, requires choosing one of the four different emotional states of the "Garfield" cat character created by Jim Davis. These emotional states are represented by Garfield's pictures of "very happy," "a little happy," "a little sad," and "very sad" and are graded from 4 points to 1 point. Cronbach's alpha value, which shows the internal consistency of the scale, was determined to be .88 for the first factor, .78 for the second factor, and .88 for the overall scale. These values indicate that the scale can make reliable measurements in terms of internal consistency (Kocaarslan, 2016).

\subsection{Data Analysis}

SPSS was used in the data analysis. Percentage and frequency were calculated among descriptive statistical methods for demographic data. Furthermore, the data were analyzed by the t-test and ANOVA. 


\section{Results}

Table 11. Descriptive Statistical Results of Primary School Students' Attitudes Towards Reading

\begin{tabular}{llll}
\hline Scale and sub dimensions & $\mathrm{N}$ & $\overline{\mathrm{X}}$ & $\mathrm{sd}$ \\
\hline Leisure reading & 534 & 3,30 &, 533 \\
Academic reading & 534 & 3,31 &, 439 \\
General total & 534 & 3,31 &, 426 \\
\hline
\end{tabular}

When Table 11 was examined, it was observed that primary school students' attitudes towards reading were at a high level according to the leisure reading sub-scale with $\overline{\mathrm{X}}=3.30$, at a high level according to the academic reading sub-scale with $\bar{X}=3.31$, and at a high level in the general total with $\bar{X}=3.31$.

Table 12. T-Test Results Showing Whether Primary School Students' Attitudes Towards Reading Differ According to the Gender Variable

\begin{tabular}{llllllll}
\hline Scale and sub dimensions & Gender & $\mathrm{N}$ & $\overline{\mathrm{X}}$ & $\mathrm{sd}$ & $\mathrm{df}$ & $\mathrm{T}$ & $\mathrm{P}$ \\
\hline Leisure reading & Female & 254 & 3,40 &, 535 & 532 & 3,979 &, 000 \\
& Male & 280 & 3,22 &, 517 & & & \\
Academic reading & Female & 254 & 3,35 &, 441 & 532 & 2,039 &, 042 \\
& Male & 280 & 3,27 &, 435 & & & \\
\multirow{2}{*}{ Total reading attitude } & Female & 254 & 3,37 &, 418 & 532 & 3,535 &, 000 \\
& Male & 280 & 3,25 &, 425 & & & \\
\hline
\end{tabular}

Upon examining Table 12, primary school students' attitudes towards reading show a statistically significant difference according to the gender variable in the leisure reading [ $\mathrm{t}(532)=3.979 ; \mathrm{p}<.05]$ and academic reading $[\mathrm{t}(532)=2.039 ; \mathrm{p}<.05]$ sub-scales and the total scores $[\mathrm{t}(532)=3.535 ; \mathrm{p}<.05]$. This difference is in favor of female students. Female students have higher attitudes towards reading.

Table 13. T-Test Results Showing Whether Primary School Students' Attitudes Towards Reading Differ According to the Variable of the Status of Reading Books and Magazines

\begin{tabular}{llllllll}
\hline Scale and sub dimensions & Status of Reading Books and Magazines & $\mathrm{N}$ & $\overline{\mathrm{X}}$ & $\mathrm{sd}$ & $\mathrm{df}$ & $\mathrm{T}$ & $\mathrm{P}$ \\
\hline Leisure reading & Yes & 350 & 3,36 &, 517 & 532 & 3,647 &, 000 \\
& No & 184 & 3,19 &, 545 & & & \\
Academic reading & Yes & 350 & 3,35 &, 429 & 532 & 2,547 &, 011 \\
& No & 184 & 3,25 &, 451 & & & \\
Total reading attitude & Yes & 350 & 3,35 &, 420 & 532 & 3,595 &, 000 \\
& No & 184 & 3,22 &, 426 & & & \\
\hline
\end{tabular}

When Table 13 is examined, it is observed that primary school students' attitudes towards reading show a statistically significant difference according to the variable of the status of reading books and magazines in the leisure reading $[\mathrm{t}(532)=3.647 ; \mathrm{p}<.05]$ and academic reading $[\mathrm{t}(532)=2.547 ; \mathrm{p}<.05]$ sub-scales and the total scores $[t(532)=3.595 ; \mathrm{p}<.05]$. This difference is in favor of those who read books and magazines. Those who read books and magazines have higher attitudes towards reading.

Table 14. T-Test Results Showing Whether Primary School Students' Attitudes Towards Reading Differ According to the Variable of the Status of Buying Books and Magazines to Read

\begin{tabular}{llllllll}
\hline $\begin{array}{l}\text { Scale and } \\
\text { sub dimensions }\end{array}$ & $\begin{array}{l}\text { Status of Buying Books and } \\
\text { Magazines to Read }\end{array}$ & $\mathrm{N}$ & $\overline{\mathrm{X}}$ & $\mathrm{sd}$ & $\mathrm{df}$ & $\mathrm{t}$ & $\mathrm{P}$ \\
\hline Leisure reading & Yes & 404 & 3,35 &, 503 & 532 & 3,948 &, 000 \\
& No & 130 & 3,14 &, 590 & & & \\
Academic reading & Yes & 404 & 3,33 &, 442 & 532 & 1,780 &, 076 \\
& No & 130 & 3,25 &, 426 & & & \\
\multirow{2}{*}{ Total reading attitude } & Yes & 404 & 3,34 &, 418 & 532 & 3,379 &, 001 \\
& No & 130 & 3,20 &, 435 & & & \\
\hline
\end{tabular}

When Table 14 is examined, it is observed that primary school students' attitudes towards reading exhibit a statistically significant difference according to the variable of the status of buying books and magazines to read 
in the leisure reading sub-scale $[\mathrm{t}(532)=3.948 ; \mathrm{p}<.05]$ and the total scores $[\mathrm{t}(532)=3.379 ; \mathrm{p}<.05]$. This difference is in favor of those who buy books and magazines to read. Those who buy books and magazines to read have higher attitudes towards reading.

Primary school students' attitudes towards reading do not show a statistically significant difference according to the variable of the status of buying books and magazines to read in the academic reading sub-scale $[\mathrm{t}(532)=$ $1.780 ; \mathrm{p}>.05]$.

Table 15. T-Test Results Showing Whether Primary School Students' Attitudes Towards Reading Differ According to the Variable of the Status of Liking Being Gifted with a Book

\begin{tabular}{llllllll}
\hline $\begin{array}{l}\text { Scale and } \\
\text { sub dimensions }\end{array}$ & $\begin{array}{l}\text { Status of Liking Being } \\
\text { Gifted with a Book }\end{array}$ & $\mathrm{N}$ & $\overline{\mathrm{X}}$ & $\mathrm{sd}$ & $\mathrm{df}$ & $\mathrm{T}$ & $\mathrm{P}$ \\
\hline Leisure reading & Yes & 493 & 3,33 &, 521 & 532 & 4,730 &, 000 \\
& No & 41 & 2,93 &, 534 & & & \\
Academic reading & Yes & 493 & 3,33 &, 430 & 532 & 2,668 &, 008 \\
& No & 41 & 3,14 &, 508 & & & \\
\multirow{2}{*}{ Total reading attitude } & Yes & 493 & 3,33 &, 415 & 532 & 4,332 &, 000 \\
& No & 41 & 3,03 &, 471 & & & \\
\hline
\end{tabular}

Upon examining Table 15, primary school students' attitudes towards reading exhibit a statistically significant difference according to the variable of the status of liking being gifted with a book in the leisure reading $[\mathrm{t}(532)=$ 4.730; $\mathrm{p}<.05]$ and academic reading [t(532)= 2.668; $\mathrm{p}<.05]$ sub-scales and the total scores [ $\mathrm{t}(532)=4.332 ; \mathrm{p}<.05]$. This difference is in favor of those who like being gifted with a book. Those who like being gifted with a book have higher attitudes towards reading.

Table 16. One-Way ANOVA Results Showing Whether Primary School Students' Attitudes Towards Reading Differ According to the Variable of Their Grade Level

\begin{tabular}{|c|c|c|c|c|c|c|c|}
\hline $\begin{array}{l}\text { Scale and sub } \\
\text { dimensions }\end{array}$ & $\begin{array}{l}\text { Source of } \\
\text { the Variance }\end{array}$ & $\begin{array}{l}\text { Sum of } \\
\text { Squares }\end{array}$ & $\mathrm{df}$ & $\begin{array}{l}\text { Mean } \\
\text { Square }\end{array}$ & $\mathrm{F}$ & $\mathrm{p}$ & $\begin{array}{l}\text { significant } \\
\text { difference }\end{array}$ \\
\hline \multirow[t]{3}{*}{ Leisure reading } & Intergroups & 2,824 & 2 & 1,412 & 5,041 & ,007 & $2-3,4-3$ \\
\hline & Intragroup & 148,735 & 531 & ,280 & & & \\
\hline & Total & 151,559 & 533 & & & & \\
\hline \multirow[t]{3}{*}{ Academic reading } & Intergroups & 2,467 & 2 & 1,233 & 6,515 & ,002 & $2-3,2-4$ \\
\hline & Intragroup & 100,528 & 531 & , 189 & & & \\
\hline & Total & 102,995 & 533 & & & & \\
\hline \multirow[t]{3}{*}{ Total reading attitude } & Intergroups & 2,438 & 2 & 1,219 & 6,834 & ,001 & $2-3,2-4,4-3$ \\
\hline & Intragroup & 94,726 & 531 & ,178 & & & \\
\hline & Total & 97,165 & 533 & & & & \\
\hline
\end{tabular}

Upon examining Table 16, it is observed that primary school students' attitudes towards reading exhibit a statistically significant difference according to the variable of their grade level in the leisure reading $[\mathrm{F}(2 ; 531)=$ 5.041; $\mathrm{P}<.05]$ and academic reading $[\mathrm{F}(2 ; 531)=6.515 ; \mathrm{P}<.05]$ sub-scales and total scores $[\mathrm{F}(2 ; 531)=6.834$; $\mathrm{P}<.05]$.

LSD and Scheffe's tests were conducted to determine between which groups this significant difference existed. This difference found is indicated in the significant difference column of the table. There is a significant difference between the $2^{\text {nd }}$ and $3^{\text {rd }}$ grades in the leisure reading sub-scale according to the variable of the grade level of primary school students. This difference is in favor of $2^{\text {nd }}$ grades. It can be said that primary school $2^{\text {nd }}$-grade students' reading attitudes towards the leisure reading sub-scale are higher than those of $3^{\text {rd }}$-grade students. There is a significant difference between the $4^{\text {th }}$ and $3^{\text {rd }}$ grades in the leisure reading sub-scale according to the variable of the grade level of primary school students. This difference is in favor of $4^{\text {th }}$ grades. It can be said that primary school $4^{\text {th }}$-grade students' reading attitudes towards the leisure reading sub-scale are higher than those of $3^{\text {rd }}$-grade students.

There is a significant difference between the $2^{\text {nd }}$ and $3^{\text {rd }}$ grades in the academic reading sub-scale according to the variable of the grade level of primary school students. This difference is in favor of $2^{\text {nd }}$ grades. It can be said that primary school $2^{\text {nd }}$-grade students' reading attitudes towards the academic reading sub-scale are higher than those of $3^{\text {rd }}$-grade students. There is a significant difference between the $2^{\text {nd }}$ and $4^{\text {th }}$ grades in the academic 
reading sub-scale according to the variable of the grade level of primary school students. This difference is in favor of $2^{\text {nd }}$ grades. It can be said that primary school $2^{\text {nd }}$-grade students' reading attitudes towards the academic reading sub-scale are higher than those of $4^{\text {th }}$-grade students.

There is a significant difference in the attitudes of primary school students towards reading between the $2^{\text {nd }}$ and $3^{\text {rd }}$ grades according to the variable of their grade level in the general total. This difference is in favor of $2^{\text {nd }}$ grades. It can be said that primary school $2^{\text {nd }}$-grade students' attitudes towards general reading are higher than those of $3^{\text {rd }}$-grade students. There is a significant difference between the $2^{\text {nd }}$ and $4^{\text {th }}$ grades. This difference is in favor of $2^{\text {nd }}$ grades. It can be said that primary school $2^{\text {nd }}$-grade students' attitudes towards general reading are higher than those of $4^{\text {th }}$-grade students. There is a significant difference between the $4^{\text {th }}$ and $3^{\text {rd }}$ grades. This difference is in favor of $4^{\text {th }}$ grades. It can be said that primary school $4^{\text {th }}$-grade students' attitudes towards general reading are higher than those of $3^{\text {rd }}$-grade students.

Table 17. One-Way ANOVA Results Showing Whether Primary School Students' Attitudes Towards Reading Differ According to the Variable of the Number of Books Read per Week

\begin{tabular}{|c|c|c|c|c|c|c|c|}
\hline $\begin{array}{l}\text { Scale and } \\
\text { sub dimensions }\end{array}$ & $\begin{array}{l}\text { Source of } \\
\text { the Variance }\end{array}$ & $\begin{array}{l}\text { Sum of } \\
\text { Squares }\end{array}$ & $\mathrm{df}$ & $\begin{array}{l}\text { Mean } \\
\text { Square }\end{array}$ & $\mathrm{F}$ & $\mathrm{p}$ & significant difference \\
\hline \multirow[t]{4}{*}{ Leisure reading } & Intergroups & 15,171 & 4 & 3,793 & 14,711 & 000 & $1-0,2-0,3-0,4-0,2-1,3-1,4-1$ \\
\hline & Intragroup & 136,387 & 529 &, 258 & & & \\
\hline & Total & 151,559 & 533 & & & & \\
\hline & Intergroups & 5,261 & 4 & 1,315 & 7,119 &, 000 & $1-0,2-0,3-0,4-0,3-1,4-1,3-2$, \\
\hline \multirow{2}{*}{$\begin{array}{l}\text { Academic } \\
\text { reading }\end{array}$} & & & & & & & $4-2$ \\
\hline & Intragroup & 97,734 & 529 &, 185 & & & \\
\hline \multirow[t]{3}{*}{$\begin{array}{l}\text { Total reading } \\
\text { attitude }\end{array}$} & Intergroups & $\begin{array}{l}102,993 \\
8,992\end{array}$ & $\begin{array}{l}533 \\
4\end{array}$ & 2,248 & 13,488 &, 000 & $\begin{array}{l}1-0,2-0,3-0,4-0,2-1,3-1,4-1 \text {, } \\
4-2\end{array}$ \\
\hline & Intragroup & 88,172 & 529 & 167 & & & \\
\hline & Total & 97,165 & 533 & & & & \\
\hline
\end{tabular}

Upon examining Table 17, primary school students' attitudes towards reading exhibit a statistically significant difference according to the variable of the number of books read per week in the leisure reading $[F(4 ; 529)=$ $14.711 ; \mathrm{P}<.05]$ and academic reading $[\mathrm{F}(4 ; 529)=7.119 ; \mathrm{P}<.05]$ sub-scales and the total scores $[\mathrm{F}(4 ; 529)=$ 13.488; $\mathrm{P}<.05]$.

LSD and Scheffe's tests were conducted to determine between which groups this significant difference existed. This difference found is indicated in the significant difference column of the table. According to the variable of the number of books read by primary school students per week, there is a significant difference in the leisure reading sub-scale between students reading one book per week and not reading at all in favor of those reading one book per week; between students reading two books per week and not reading at all in favor of those reading two books per week; between students reading three books per week and not reading at all in favor of those reading three books per week; between students reading four books per week and not reading at all in favor of those reading four books per week; between students reading two books and one book per week in favor of those reading two books per week; between students reading three books and one book per week in favor of those reading three books per week, and between students reading four books and one book per week in favor of those reading four books per week. It can be said that those who read more books per week have higher reading attitudes.

According to the variable of the number of books read by primary school students per week, there is a significant difference in the academic reading sub-scale between students reading one book per week and not reading at all in favor of those reading one book per week; between students reading two books per week and not reading at all in favor of those reading two books per week; between students reading three books per week and not reading at all in favor of those reading three books per week; between students reading four books per week and not reading at all in favor of those reading four books per week; between students reading three books and one book per week in favor of those reading three books per week; between students reading four books and one book per week in favor of those reading four books per week; and between students reading three books and two books per week in favor of those reading three books per week, and between students reading four and two books per week in favor of those reading four books per week. It can be said that those who read more books per week have higher reading attitudes. 
According to the variable of the number of books read by primary school students per week, there is a significant difference in the total scores between students reading one book per week and not reading at all in favor of those reading one book per week; between students reading two books per week and not reading at all in favor of those reading two books per week; between students reading three books per week and not reading at all in favor of those reading three books per week; between students reading four books per week and not reading at all in favor of those reading four books per week; between students reading two books and one book per week in favor of those reading two books per week; between students reading three books and one book per week in favor of those reading three books per week; between students reading four books and one book per week in favor of those reading four books per week; and between students reading four books and two books per week in favor of those reading four books per week. It can be said that those who read more books per week have higher reading attitudes.

Table 18. One-Way ANOVA Results Showing Whether Primary School Students' Attitudes Towards Reading Differ According to the Variable of Their Favorite Book Type

\begin{tabular}{lllllll}
\hline $\begin{array}{l}\text { Scale and sub } \\
\text { dimensions }\end{array}$ & $\begin{array}{l}\text { Source of the } \\
\text { Variance }\end{array}$ & $\begin{array}{l}\text { Sum of } \\
\text { Squares }\end{array}$ & $\mathrm{df}$ & $\begin{array}{l}\text { Mean } \\
\text { Square }\end{array}$ & $\mathrm{F}$ & $\mathrm{p}$ \\
\hline Leisure reading & Intergroups &, 460 & 4 &, 115 &, 403 &, 807 \\
& Intragroup & 151,098 & 529 &, 286 & & \\
& Total & 151,559 & 533 & & & \\
& Intergroups &, 988 & 4 &, 247 & 1,281 &, 276 \\
Academic reading & Intragroup & 102,007 & 529 &, 193 & & \\
& Total & 102,995 & 533 & & & \\
Total reading attitude & Intergroups &, 596 & 4 &, 149 &, 817 &, 515 \\
& Intragroup & 96,568 & 529 &, 183 & & \\
& Total & 97,165 & 533 & & & \\
\hline
\end{tabular}

Upon examining Table 18, it is observed that primary school students' attitudes towards reading do not exhibit a statistically significant difference according to the variable of their favorite book type in the leisure reading $[\mathrm{F}(4$; $529)=.403 ; \mathrm{P}>.05]$ and academic reading $[\mathrm{F}(4 ; 529)=1.281 ; \mathrm{P}>.05]$ sub-scales and the total scores $[\mathrm{F}(4 ;$ $529)=.817 ; \mathrm{P}>.05]$.

Table 19. One-Way ANOVA Results Showing Whether Primary School Students' Attitudes Towards Reading Differ According to the Variable of the Number of Siblings

\begin{tabular}{|c|c|c|c|c|c|c|c|}
\hline $\begin{array}{l}\text { Scale and } \\
\text { sub dimensions }\end{array}$ & $\begin{array}{l}\text { Source of the } \\
\text { Variance }\end{array}$ & $\begin{array}{l}\text { Sum of } \\
\text { Squares }\end{array}$ & df & $\begin{array}{l}\text { Mean } \\
\text { Square }\end{array}$ & $\mathrm{F}$ & $\mathrm{p}$ & $\begin{array}{l}\text { Significant } \\
\text { difference }\end{array}$ \\
\hline \multirow[t]{4}{*}{ Leisure reading } & Intergroups & 4,316 & 5 &, 863 & 3,095 & ,009 & $3-2,4-1,4-2$ \\
\hline & Intragroup & 147,242 & 528 & 279 & & & \\
\hline & Total & 151,559 & 533 & & & & \\
\hline & Intergroups & 612 & 5 & ,122 & 631 & ,676 & \\
\hline \multirow[t]{2}{*}{ Academic reading } & Intragroup & 102,383 & 528 & ,194 & & & \\
\hline & Total & 102,995 & 533 & & & & \\
\hline \multirow[t]{3}{*}{ Total reading attitude } & Intergroups & 1,878 & 5 & ,376 & 2,081 & ,066 & \\
\hline & Intragroup & 95,286 & 528 & , 180 & & & \\
\hline & Total & 97,165 & 533 & & & & \\
\hline
\end{tabular}

When Table 19 is examined, it is observed that primary school students' attitudes towards reading exhibit a statistically significant difference according to the variable of the number of siblings in the leisure reading $[\mathrm{F}(5$; 528) $=3.095 ; \mathrm{P}<.05]$ subscale.

LSD and Scheffe's tests were conducted to determine between which groups this significant difference existed. This difference found is indicated in the significant difference column of the table. According to the variable of the number of siblings of primary school students, there is a significant difference in favor of those with 3 siblings in the leisure reading sub-scale between those with 3 siblings and 2 siblings. There is a significant difference between those with 4 siblings and 1 sibling in favor of those with four siblings. There is a significant difference between those with 4 siblings and 2 siblings in favor of those with four siblings. Those with more siblings have higher attitudes towards reading. 
Primary school students' attitudes towards reading do not exhibit a statistically significant difference according to the variable of the number of siblings in the academic reading sub-scale $[\mathrm{F}(5 ; 528)=.631 ; \mathrm{P}>.05]$ and the total scores $[\mathrm{F}(5 ; 528)=2.081 ; \mathrm{P}>.05]$.

Table 20. One-Way ANOVA Results Showing Whether Primary School Students' Attitudes Towards Reading Differ According to the Variable of the Mother's Educational Status (One-Way ANOVA)

\begin{tabular}{|c|c|c|c|c|c|c|}
\hline Scale and sub dimensions & Source of the Variance & Sum of Squares & $\mathrm{df}$ & Mean Square & $\mathrm{F}$ & $\mathrm{p}$ \\
\hline \multirow[t]{4}{*}{ Leisure reading } & Intergroups & 1,368 & 5 & 274 & ,962 & ,441 \\
\hline & Intragroup & 150,190 & 528 & ,284 & & \\
\hline & Total & 151,559 & 533 & & & \\
\hline & Intergroups & 1,844 & 5 & ,369 & 1,926 & ,088 \\
\hline \multirow[t]{2}{*}{ Academic reading } & Intragroup & 101,151 & 528 & ,192 & & \\
\hline & Total & 102,995 & 533 & & & \\
\hline \multirow[t]{3}{*}{ Total reading attitude } & Intergroups & 1,478 & 5 & ,296 & 1,631 &, 150 \\
\hline & Intragroup & 95,687 & 528 & ,181 & & \\
\hline & Total & 97,165 & 533 & & & \\
\hline
\end{tabular}

Upon examining Table 20, primary school students' attitudes towards reading do not exhibit a statistically significant difference according to the variable of the mother's educational status in the leisure reading $[\mathrm{F}(5$; $528)=.962 ; \mathrm{P}>.05]$ and academic reading $[\mathrm{F}(5 ; 528)=1.926 ; \mathrm{P}>.05]$ sub-scales and the total scores $[\mathrm{F}(5 ; 528)=$ $1.631 ; \mathrm{P}>.05]$.

Table 21. One-Way ANOVA Results Showing Whether Primary School Students' Attitudes Towards Reading Differ According to the Variable of the Father's Educational Status

\begin{tabular}{|c|c|c|c|c|c|c|}
\hline Scale and sub dimensions & Source of the Variance & Sum of Squares & $\mathrm{df}$ & Mean Square & $\mathrm{F}$ & $\mathrm{p}$ \\
\hline \multirow[t]{4}{*}{ Leisure reading } & Intergroups & ,858 & 5 & 172 & 601 & ,699 \\
\hline & Intragroup & 150,701 & 528 & 285 & & \\
\hline & Total & 151,559 & 533 & & & \\
\hline & Intergroups & 1,574 & 5 & ,315 & 1,639 & , 148 \\
\hline \multirow[t]{2}{*}{ Academic reading } & Intragroup & 101,421 & 528 & 192 & & \\
\hline & Total & 102,995 & 533 & & & \\
\hline \multirow[t]{3}{*}{ Total reading attitude } & Intergroups & 1,165 & 5 & ,233 & 1,281 & ,271 \\
\hline & Intragroup & 96,000 & 528 & 182 & & \\
\hline & Total & 97,165 & 533 & & & \\
\hline
\end{tabular}

When Table 21 is examined, it is observed that primary school students' attitudes towards reading do not exhibit a statistically significant difference according to the variable of the father's educational status in the leisure reading $[\mathrm{F}(5 ; 528)=.601 ; \mathrm{P}>.05]$ and academic reading $[\mathrm{F}(5 ; 528)=1.639 ; \mathrm{P}>.05]$ sub-scales and the total scores $[\mathrm{F}(5 ; 528)=1.281 ; \mathrm{P}>.05]$.

\section{Conclusion}

It was observed that primary school students had a high level of attitudes towards reading.

Primary school students' attitudes towards reading exhibit a statistically significant difference in the leisure reading and academic reading sub-scales and their total scores according to the variables of gender, the status of reading books and magazines, and the status of liking being gifted with a book. This difference is in favor of female students, those who read books and magazines, and those who like being gifted with a book. Female students, those who read books and magazines, and those who like being gifted with a book have higher attitudes towards reading.

Primary school students' attitudes towards reading show a statistically significant difference in the leisure reading sub-scale and their total scores according to the variable of the status of buying books and magazines to read. This difference is in favor of those who buy books and magazines to read.

Primary school students' attitudes towards reading exhibit a statistically significant difference in the leisure reading sub-scale according to the number of siblings variable. This significant difference is in favor of those with three siblings between those with three siblings and two siblings, in favor of those with four siblings between those with four siblings and one sibling, in favor of those with four siblings between those with four 
siblings and two siblings.

Primary school students' attitudes towards reading show a statistically significant difference in the leisure reading and academic reading sub-scales and their total scores according to the variables of their grade level and the number of books they read per week.

Primary school students' attitudes towards reading do not exhibit a statistically significant difference according to the variables of the educational status of parents and their favorite book type.

\section{Discussion}

According to the recent studies, the human starts learning from the mother's womb. The individual is in a learning activity from birth to death. The person performs an informal or formal, positive or negative learning action. Reading and attitude are also among these activities and are the learning that the individual acquires later. The attitudes and behaviors determined by the person affect the person's attitude towards reading. When the literature is reviewed, it is observed that there are very few studies conducted to examine primary school attitudes towards reading. However, there are studies on a similar subject in different school types. The results of this study we conducted on the relationship between reading and attitude are presented below.

As a result of the data analysis, it was observed that primary school students' attitudes towards reading were at a high level. In the study conducted by Şahin-Taşkın and Esen-Aygün (2017), it is observed that the third and fourth-grade students' leisure reading attitudes are at 'a little unhappy' level and their academic reading attitudes are at 'a little happy' level. As a result of the study carried out by Özdemir and Şerbetçi (2018), it was observed that students had a strong reading attitude. According to the results of the study performed by İzci (2013), it was determined that $5^{\text {th }}$-grade students' attitudes towards reading were at a high level. As a result of the application performed by Başaran and Ateş (2009), it was observed that the majority of students developed a high level of positive attitudes towards reading. As a result of the study conducted by Yildız and Kaman (2016), it was determined that there was a significant difference between the $2^{\text {nd }}$ and $3^{\text {rd }}$ grades of primary school and $5^{\text {th }}$ and $6^{\text {th }}$ grades of secondary school in terms of reading attitudes, and the reading attitude, which was high in the first years of primary education, decreased in the first years of secondary school. In the study conducted by Nootens et al (2019) results showed that their stated attitudes toward reading remained stable across the final 2 years of elementary school, as well as across the first 2 years of middle school, but differences were observed for the transition from one education level to the next, with stated attitudes toward reading being less positive in the latter. It is observed that the results of this study are similar to the results of other studies.

In the study conducted by Ley, Schaer and Dismukes (1994 students reported their general attitude toward reading and the values that they placed upon reading for three distinct purposes. These purposes are individual development, utilitarian and enjoyment.

Primary school students' attitudes towards reading exhibit a statistically significant difference in the leisure reading and academic reading sub-scales and their total scores according to the variables of gender, the status of reading books and magazines, and liking being gifted with a book. This difference is in favor of female students, those who read books and magazines, and those who like being gifted with a book. Female students, those who read books and magazines, and those who like being gifted with a book have higher attitudes towards reading. According to the results of the study carried out by Yildız and Kaman (2016), while female students' attitudes towards leisure reading were more positive than those of male students, no significant difference was found in the academic reading attitude. As a result of the study carried out by Özdemir and Şerbetçi (2018), it was observed that the reading attitude of female students was higher than that of male students. As a result of the study carried out by Worrell, Roth and Gabelko (2006) significantly higher scores on reading attitudes were found for girls at three grade levels, with medium to large effect sizes. As a result of the study carried out by Vatansever Bayraktar (2017) primary school students' perceptions of reading motivation differ significantly according to the gender variable. There is a significant difference in favor of boys in the sub-dimension of perceiving reading difficulty and in favor of girls in the sub-dimension of effort / appreciation for reading. The findings obtained from the study conducted by Şahin-Taşkın and Esen-Aygün (2017) draw attention to the fact that female and male students' leisure reading and academic reading attitudes do not differ significantly. While the research results obtained by Şahin-Taşkın and Esen-Aygün (2017) differ from the results of the present study, there are studies showing that female students' reading attitudes are more positive than male students' reading attitudes (Can, Türkyılmaz and Karadeniz, 2010; Batur, Gülveren and Bek, 2010; Sallabaş, 2008; Başaran and Ateş, 2009; Balc1, Uyar and Büyükikiz, 2012; Akkaya and Özdemir 2013). The results of the study conducted are similar to these studies. Likewise, as a result of the study performed by Gür-Erdoğan and Demir (2016), it was found that female students' attitudes towards reading were significantly higher than those of male students 
and students who had bookcases at home had significantly higher attitudes towards reading compared to those who did not. As a result of the study, the attitudes towards reading of those who read books and magazines were found to be higher. As a result of the study carried out by Gür-Erdoğan and Demir (2016), it was found that individuals with high attitudes towards reading had a higher frequency of reading books. As a result of the study performed by Akkaya and Özdemir (2013), it was revealed that secondary school students' attitudes towards reading had a moderate and positive relationship with the number of books read in both the overall scale and in all sub-scales. In the relevant literature, there are studies showing that there is a positive relationship between the reading attitude and the number of books read, which is accepted as an indicator of reading habits (Stokmans 1999; Schooten \& Glopper 2002; Özbay, Bağc1 and Uyar, 2008; Bağc1, 2010, Doğan-Yılmaz 2010; Balc1, Uyar and Büyükikiz, 2012).

Primary school students' attitudes towards reading show a statistically significant difference in the leisure reading sub-scale and their total scores according to the variable of the status of buying books and magazines to read. This difference is in favor of those who buy books and magazines to read. Primary school students' attitudes towards reading exhibit a statistically significant difference in the leisure reading sub-scale according to the variable of the number of siblings. This significant difference is in favor of those with three siblings between those with three siblings and two siblings, in favor of those with four siblings between those with four siblings and one sibling, in favor of those with four siblings between those with four siblings and two siblings. Primary school students' attitudes towards reading show a statistically significant difference in the leisure reading and academic reading sub-scales and their total scores according to the variables of their grade level and the number of books they read per week. When evaluated in terms of grade level, it is observed that the leisure reading and academic reading attitudes of third-grade students are more positive than those of fourth-grade students (Şahin-Taşkın, Esen-Aygün, 2017).

Primary school students' attitudes towards reading do not exhibit a statistically significant difference according to the variables of the educational status of parents and their favorite book type. When the literature is reviewed, it is observed that there is a significant difference (Can, Türkyılmaz and Karadeniz, 2010; Durualp. Durualp and Çiçekoğlu, 2013) and there is not a significant difference between primary school students' reading attitudes and their parents' education levels (Demir-Atalay, 2009; Sadioğlu and Bilgin, 2008; Batur, Gülveren and Bek, 2010; Şahin-Taşkın and Esen-Aygün, 2017; Gür-Erdoğan and Demir, 2016).

\section{Recommendations}

As a result of the study, the reading attitudes of male students were found to be lower. Teachers can prepare activities that encourage reading to improve the reading attitudes of male students. Male students can be encouraged by giving more tasks to them at reading festivals and animation of in-class reading texts, ceremonies, etc.

This study covers primary school students. Comparisons can also be made by examining the reading attitudes of students at different levels. This research is a quantitative study. Qualitative and quantitative studies can be conducted on the subject. The relationship between students' reading attitudes and different variables can be examined. Longitudinal studies can be carried out with the primary school students participating in this study. The sample group in this study included primary school students in Avcılar and Beylikdüzü districts of Istanbul province. The study can be repeated with the extended sample group to include different regions and provinces.

\section{Acknowledgement}

This study is the expanded version of the paper presented at the International Strategic and Social Research Symposium (ISASOR) on May 03-05, 2018.

\section{References}

Akçamete, G., \& Güneş, F. (1992). Üniversite öğrencilerinin okumalarının değerlendirilmesi. Ankara Üniversitesi Ĕgitim Bilimleri Fakültesi Dergisi, 25(2), 463-471.

Akkaya, N., \& Özdemir, S. (2013). Ortaöğretim Öğrencilerinin Okumaya Yönelik tutumlarının İncelenmesi (İzmir-Buca Örneği). Bartın Üniversitesi Eğitim Fakültesi Dergisi, 2(1), 75-96. https://doi.org/10.14686/201312019

Akyol, H., \& Temur, T. (2008). Ses Temelli Cümle Yöntemi ve Cümle Yöntemi ile Okuma Yazma Öğrenen Öğrencilerin Okuma Becerilerinin Öğretmen Görüşlerine Göre Değerlendirilmesi, Mustafa Kemal Üniversitesi Sosyal Bilimler Enstitüsü Dergisi, 5(9), 79-95.

Arıcı, A. F. (2012). Okuma eğitimi. Ankara: Pegem Akademi Yayıncılık. 
Bağc1, H. (2010). İlköğretim II. Kademe Öğrencilerinin Okumaya Yönelik Tutumlarının Değerlendirilmesi. II. Uluslararası Dünya Dili Türkçe Sempozyumu. Uluslararası Kıbrıs Üniversitesi, 9-11 Aralık 2009, Lefkoşa.

Balci, A., Uyar, Y., \& Büyükikiz, K. K. (2012). İlköğretim 6. sınıf öğrencilerinin okuma alışkanlıkları, kütüphane kullanma sıklıkları ve okumaya yönelik tutumlarının incelenmesi. Turkish Studies-International Periodical for the Languages. Literature and History of Turkish or Turkic, 7(4), 965-985.

Başaran, M., \& Ateş, S. (2009). İlköğretim Beşinci Sınıf Öğrencilerinin Okumaya İlişkin Tutumlarının İncelenmesi. Gazi Ĕgitim Fakültesi Dergisi, 29(1), 73-92.

Batur, Z., Gülveren, H., \& Bek, H. (2010). Öğretmen Adaylarının Okuma Alışkanlıkları Üzerine Bir Araştırma: Uşak Eğitim Fakültesi Örneği. Uş̧ak Üniversitesi Sosyal Bilimler Dergisi, 3(1). 32-49. https://doi.org/10.12780/UUSBD61

Can, R., Türkyılmaz, M., \& Karadeniz, A. (2010). Ergenlik Dönemi Öğrencilerinin Okuma Alışkanlıkları. Ahi Evran Üniversitesi Eğitim Fakültesi Dergisi, 11(3), 1-21.

Çeliktürk, Z., \& Yamaç, A. (2015). İlkokul ve Ortaokul Öğrencileri İçin Okuma Kaygısı Ölçeğinin Geliştirilmesi: Geçerlik ve Güvenirlik Çalışması. İlköğretim Online, 14(1), 97-107. https://doi.org/10.17051/io.2016.42123

Demir-Atalay, T. (2009). İlköğretim II. Kademe Öğretmen Adaylarının Okuma Alışkanlıkları Üzerine Bir Araştırma (Gazi Üniversitesi Örneği). Turkish Studies, 4(3), 717-745.

Doğan Yılmaz, E. (2010). Hemşirelik Öğrencilerinin Eleştirel Düşünme Düzeyleri ve Kitap Okuma Alışkanllğına İlişkin Tutumları. Yüksek Lisans Tezi. Hacettepe Üniversitesi, Ankara.

Dökmen, Ü. (1994). Okuma Becerisi, İlgisi ve Allşkanlı̆̆ Üzerine Psiko-Sosyal Bir Araştırma. İstanbul: Milli Eğitim Bakanlığı Yayınları

Durualp, E., Durualp, E., \& Çiçekoğlu, P. (2013). 6-8. sınıftaki öğrencilerin okumaya ilişkin tutumlarının bazı değişkenler açısından incelenmesi. Çankırı Karatekin Üniversitesi SBE Dergisi, 4(1), 159-174.

Güneş, F. (2009). Hızlı okuma ve anlamı yapılandırma. Ankara: Nobel Yayın Dağıtım.

Gür, E. D., \& Demir, Y. (2016). İlkokul 4. Sınıf Öğrencilerinin Okumaya Yönelik Tutumlarının Farklı Değişkenler Açısından İncelenmesi. Sakarya Üniversitesi Eğitim Fakültesi Dergisi, 0(32), 85-96.

İnceoğlu, M. (2010). Tutum Algı İletişim, İstanbul: Beykent Üniversitesi Yayınları.

İşeri, K. (2010). İlköğretim ikinci kademe öğrencilerinin okuma tutumlarının incelenmesi Uluslararası İnsan Bilimleri Dergisi, 7(2), 468-487

İzci, G. (2013). İlköğretim 5. Sinıf Öğrencilerinin Okumaya Yönelik Tutumları İle Noktalama İşaretlerini Uygulama Düzeyleri Arasındaki İlişkinin İncelenmesi, Yüksek lisans tezi, Akdeniz Üniversitesi, Eğitim Bilimleri Enstitüsü, Antalya

Karakaş, Ö. (2013). 8. sinıf öğrencilerinin okuma tutumları üzerine bir araştırma (MEB tarafindan ortaokul ögrencilerine önerilen 100 temel eser örneğinde). Yüksek lisans tezi, Afyon Kocatepe Üniversitesi, Sosyal Bilimler Enstitüsü, Afyon.

Karasar, N. (2016). Bilimsel Araştırma Yöntemleri, Ankara: Nobel Akademik Yayıncıllk.

Kocaarslan, M. (2016). "Garfield" Görselli 1-6. Sınıflar İçin Okumaya Yönelik Tutum Ölçeğinin Türkçe Uyarlama Çalışması. Illkögretim Online, 15(4), 1217-1233. http://dx.doi.org/10.17051/io.2016.25140

Kovacıŏglu, N. Ş. (2006). İlköğretim ikinci sınıflarında aile çevresi ve çocuğun okumaya karşı tutumu ile okuduğunu anlama becerisi arasındaki ilişkiler. Yayınlanmamış yüksek lisans tezi. Yıldız Teknik Üniversitesi, Sosyal Bilimler Enstitüsü, İstanbul.

Ley, T. C., Schaer, B. B., \& Dismukes, B. W. (1994). Longitudinal Study of the Reading Attitudes and Behaviors of Middle School Students. Reading Psychology, 15(1), 11-38. https://doi.org/10.1080/0270271940150102

Moore, S. C., \& Lemons, R. (1982). Measuring reading attitudes: Three dimensions, Reading World, 22(1), 48-57. https://doi.org/10.1080/19388078209557678

Nootens, P., Morin, M-F., Alamargot, D., Gonçalves, C., Venet, M., \& Labrecque, A-M. (2019). Differences in Attitudes Toward Reading: A Survey of Pupils in Grades 5 to 8. Frontiers in Psychology, 9, 2773. https://doi.org/10.3389/fpsyg.2018.02773

Özbay, M. (2009). Anlama Teknikleri: 1 Okuma Eğitimi, Ankara, Öncü Kitap. 
Özbay, M., Bağcı, H., \& Uyar, Y. (2008). Türkçe Öğretmeni Adaylarının Okuma Alışkanlı̆̆ına Yönelik Tutumlarının Çeşitli Değişkenlere Göre Değerlendirilmesi. İnönü Üniversitesi Eğitim Fakültesi Dergisi, 9(15), 117-136.

Özdemir, S., \& Şerbetçi, H. N. (2018). İlkokul Dördüncü Sınıf Öğrencilerinin Okumaya Yönelik Tutumları (Bartın Örneklemi). Ilköğretim Online, 17(4), 2110-2123. https://doi.org/10.17051/ilkonline.2019.506973

Sadioğlu, Ö., \& Bilgin, A. (2008). İlköğretim öğrencilerinin eleştirel okuma becerileri ile cinsiyet ve anne-baba eğitim durumu arasındaki ilişki. İlköğretim Online, 7(3), 814-822.

Sallabaş, M. E. (2008). İlköğretim 8 Sınıf Öğrencilerinin Okumaya Yönelik Tutumları ve Okuduğunu Anlama Becerileri Arasındaki İlişki. İnönü Üniversitesi Eğitim Fakültesi Dergis, 9(16), 141-155.

Schooten, E., \& Glopper, K. (2002). The relation between attitude toward reading adolescent literature and literary reading behavior. Poetics, 30, 169-194. https://doi.org/10.1016/S0304-422X(02)00010-4

Stokmans, M. J. W. (1999). Reading attitude and its effect on leisure time reading. Poetics, 26, 245-261. https://doi.org/10.1016/S0304-422X(99)00005-4

Şahin-Taşkın, Ç., \& Esen-Aygün, H. (2017). İlkokul Öğrencilerinin Okuma Tutumlarının Çeşitli Değiş̧kenler Açısından İncelenmesi. Illkögretim Online, 16(3), 1120-1136. https://doi.org/10.17051/ilkonline.2017.330246

Topuzkanamış, E., \& Maltepe, S. (2010). Öğretmen adaylarının okuduğunu anlama ve okuma stratejilerini kullanma düzeyleri. Türklük Bilimi Araştırmaları Dergisi, 27, 655-677.

Ülgen, G. (1997). Eğitim Psikolojisi, İstanbul: Alkım Yayınevi.

Vatansever, H. (2008). Çözümleme (Cümle) Yöntemi ve Ses Temelli Cümle Yöntemine Göre Okuma Yazma Öğrenmiş Çocukların Okuduğunu Anlamadaki Başarı Durumlarının Değerlendirilmesi, Yayımlanmamış Yüksek Lisans Tezi, Marmara Üniversitesi, Eğitim Bilimleri Enstitüsü, İstanbul.

Vatansever-Bayraktar, H. (2017). İlkokul Öğrencilerinin Okuma Motivasyonları ile İlgili Algılarının İncelenmesi, Yükseköğretimde Eğitim Araştırmaları ve Uygulamaları Kongresi (Yeauk)- 19 Mayıs 2017, İstanbul.

Vatansever-Bayraktar, H., \& İşleyen, M. (2018). Öğretmen Adaylarının Öğretim Teknolojisi ve Materyal Tasarımı Dersine Yönelik Tutumlarının İncelenmesi, Akademik Sosyal Araştırmalar Dergisi, 6(79), 208-230. https://doi.org/10.16992/ASOS.14208

Vatansever-Bayraktar, H., Kadığlu Ateş, H., \& Afat, N. (2019). An Analysis On The Relationship Between Primary School Teachers' Self-Efficacy Beliefs And Attitudes Towards Gifted Education. International Journal of Eurasia Social Sciences, 10(38), 1099-1124. https://doi.org/10.35826/ijoess.2484

Worrell, F., C., Roth, D. A., \& Gabelko, N. H. (2006). Elementary reading attitude survey (ERAS) scores in academically talented students, Roeper Review, 29(2), 119-124. https://doi.org/10.1080/02783190709554395

Yıldız, M., \& Kaman, Ş. (2016). İlköğretim (2-6. Sınıf) Öğrencilerinin Okuma Ve Yazma Tutumlarının İncelenmesi. Türkiye Sosyal Araştırmalar Dergisi, 20(2), 508-522.

Yılmaz, B. (2000). Çok kültürlü toplumlarda etnik azınlık çocuklarının okuma ve kütüphane kullanma alışkanlıkları. Türk Kütüphaneciliği, 14(4), 451-465.

\section{Copyrights}

Copyright for this article is retained by the author(s), with first publication rights granted to the journal.

This is an open-access article distributed under the terms and conditions of the Creative Commons Attribution license (http://creativecommons.org/licenses/by/4.0/). 